\title{
Genetic diversity as revealed by AFLP finger- printing and systematic relationships of species in Sesbania (Fabaceae)
}

\author{
Hanaa H. El-Shazly \\ Department of Biological and Geological Sciences, Faculty of Education, \\ Ain Shams University, Roxy, Cairo, Egypt \\ El-Shazly, H.H. 2006. Genetic diversity as revealed by AFLP finger-printing and \\ systematic relationships of species in Sesbania (Fabaceae). Taeckholmia 26: 105-120.
}

\begin{abstract}
Genetic diversity has been revealed, using AFLP finger printing, in 37 accessions representing 21 species of Sesbania. The AFLP data has been analyzed and distance trees, illustrating the relationships within and among species, have been constructed using UPGMA and neighbor joining (NJ) methods as implemented in the NTSYS-pc software. Both trees illustrated polymorphism between accessions of the same species, from different origins, but illustrated that intraspecific accessions have closer genetic affinity to each other than to other species. The NJ and UPGMA distance trees clearly delimited the species of the two subgenera Agati and Daubentonia as two separate groups from those in subgenus Sesbania. The AFLP data revealed considerable polymorphism among species of subgenus Sesbania that is not correlated with karyotype resemblances of species in this subgenus and their ability to cross. Based on AFLP data this subgenus may be regarded the center from which species in the other two subgenera have been derived. In the NJ tree $S$. quadrata and $S$. rostrata are distinguished from two large groups, but in the UPGMA tree $S$. quadrata is grouped with $S$. bispinosa and $S$. cannabina, whereas $S$. rostrata is grouped with $S$. exaltata in one of the NJ groups. The delimitation of species based on the analyses of AFLP data is discussed in the light of their systematic delimitation.
\end{abstract}

Key words: Genetic diversity, AFLP finger-printing, Sesbania, Systematics

\section{Introduction}

The genus Sesbania Scopali (Fabaceae) comprises over 60 species distributed in the tropical and subtropical regions of the World, 32 in Africa,

Received 20 October 2006, accepted 11 December 2006 
10 in Asia, 10 in Australia and eight in the Americas. Few species, e.g. $S$. sesban and $S$. sericea have been naturalized in different parts of the World and had become of a cosmopolitan distribution (Forni-Martins et al., 1994). The altitudinal range of the genus varies from sea level to $2000 \mathrm{~m}$, in regions with rainfall distribution between 500 and $2000 \mathrm{~mm}$ per year. Sesbania species are more commonly found in regions with alternating wet and dry periods than in those with evenly distributed rainfall (Evans, 1990). Several species of this genus are used as animal fodder (Monteiro, 1994) and to maintain soil productivity and improve soil structure for non legume crops (Evans \& Rotor, 1987). The species of Sesbania were delimited by Bentham (1859) in four sections i.e. Agati, Doubentonia, Sesbania and Glottidium. More recently however, section Glottidium was considered as a distinct monotypic genus and was separated from Sesbania and the other three sections have been considered as subgenera of Sesbania (Sachet, 1987; Monteiro, 1994).

In addition to the use of morphological traits for the classification of species in Sesbania, evidences derived from cytological information have been applied to address systematic and evolutionary relationships of species in the genus. Federov (1974), Goldblatt $(1985 ; 1988)$ and Goldblatt and Johnson (1991) compiled chromosome counts for about half of the species in Sesbania. More recently, Abou-El-Enain et al. (1998) and El Shazly \& Abou-El-Enain (1999) reported counts and described the karyotype for 39 taxa representing 24 species. The vast majority of the examined species have a basic chromosome number of $x=6$, but species with numbers based on $x=7$ and $x=8$ has been found. Polyploidy was encountered in a number of species; $2 n=24$ was recorded in $S$. aculeata, $S$. formosa, $S$. grandiflora, $S$. sesban, S. tetraptera, and $S$. virgata, whereas $2 n=28$ was only found in $S$. pachycarpa. Detailed karyotypic data have been described for several species (Lubis et al., 1981; Parihar \& Zadoo, 1987; Joshua \& Bhatia, 1989; Heering \& Hanson, 1993; Salimuddin, 1993; Forni-Martins et al., 1994; Abou-El-Enain et al., 1998; El Shazly \& Abou-El-Enain, 1999).

Seed storage proteins are particularly abundant in the seeds of legumes and have provided valid source of evidence that have successfully been used for addressing the systematic relationships at the species level in many genera of the family Fabaceae. For example, to differentiate between species in Trifolium (Badr, 1995), Lathyrus (Badr et al., 2000), Astragalus (AlNowaihi et al., 2002) and Lupinus (El-Shazly et al., 2006) In Sesbania, Saraswati et al. (1993) used electrophoretic patterns of seed proteins for 
species identification. The analysis of seed protein electrophoretic data showed that species in the two subgenera Agati and Daubentonia form a heterogeneous group that is distinct from species of subgenus Sesbania (Badr et al., 1998).

In recent years, molecular markers derived from DNA using electrophoretic techniques have provided powerful markers for the study genetic relationships of plant species. The amplified fragment length polymorphism (AFLP) that was published by Vos et al. (1995) has been found efficient, reliable, and convenient. This method, which defines unique dominant loci in the genome, has the capacity to produce higher number of polymorphic loci and the highest frequency of polymorphism, in a single assay, than other molecular assays (Powell et al., 1996), and has been regarded as the most popular among the molecular DNA finger-printing methods (Bachman, 1998; Martin \& Salamini, 2000).

The reliability of this approach for phylogeny reconstruction has been confirmed by the finding that in closely related species of Hordeum the comigrating bands are identical in terms of sequence homology. In that genus, phylogenies based on carefully selected AFLP bands were found to be superior to phylogenies based on ITS sequences (El-Rabey et al., 2002). Another approach utilizing AFLPs has been to elucidate the origin and domestication history of some cultivated crops, prominent examples include einkorn wheat (Heun et al., 1997) and barley (Badr et al., 2000). The potential of AFLP in systematics and evolutionary studies was also demonstrated in Lactuca (Hill et al., 1996), Solanum (Kardolus et al., 1998), Bromus (Massa, et al., 2001) and Lathyrus (Badr et al., 2002). The aim of the present work is to reassess the relationships among 37 species of Sesbania that belong to the three subgenera of the genus based on DNA fingerprints as revealed by AFLP.

\section{Material and Methods}

Seed material of 37 accessions representing 21 species of Sesbania Scopali was kindly provided by gene banks of the International Livestock Center for Africa (ILCA), Ethiopia and the United States Department of Agriculture (USDA). The source, origin, somatic chromosome number and sectional delimitation of the examined material are given in Table 1. Plants of almost all accessions have been grown in open grounds in the Botanical Garden of the Faculty of Education. 
Table 1. A list compiling names, source, origin, 2n chromosome number and subgeneric delimitation of Sesbania accessions and species used in the present study.

\begin{tabular}{|c|c|c|c|c|c|}
\hline Ser & Species & Source & Origin & 2n & Subgenus \\
\hline 01 & S. bispinosa 1 (Jacq.) Wright & USDA & India & 12 & \multirow{3}{*}{ Sesbania } \\
\hline 02 & S. bispinosa 2 & USDA & Pakistan & 12 & \\
\hline 03 & S. bispinosa 3 & ILCA & Tanzania & 12 & \\
\hline 04 & S. cannabina 1 (Retz.) Pers. & USDA & China & 12 & \multirow{2}{*}{ Sesbania } \\
\hline 05 & S. cannabina 2 & USDA & India & 12 & \\
\hline 06 & S. exaltata 1 (Raf.) Rydb. ex Hill & USDA & Australia & 12 & \multirow{3}{*}{ Sesbania } \\
\hline 07 & S. exaltata 2 & USDA & Mexico & 12 & \\
\hline 08 & S. exaltata 3 & USDA & Uruguay & 12 & \\
\hline 09 & S. exasperata 1 Kunth & USDA & Argentina & 12 & \multirow{3}{*}{ Sesbania } \\
\hline 10 & S. exasperata 2 & USDA & Brazil & 12 & \\
\hline 11 & S. exasperata 3 & USDA & Peru & 12 & \\
\hline 12 & S. formusa (F. Muell.) Burb. & ILCA & Australia & 24 & Agati \\
\hline 13 & S. goetzi Harms & ILCA & Tanzania & 12 & Sesbania \\
\hline 14 & S. grandiflora (L.) Poir & ILCA & Ethiopia & 24 & Agati \\
\hline 15 & S. greenwayi Gillett & ILCA & Tanzania & 12 & Sesbania \\
\hline 16 & S. hirtistyla Gillett & ILCA & Tanzania & 12 & Sesbania \\
\hline 17 & S. keniensis Gillett & ILCA & Ethiopia & 12 & Sesbania \\
\hline 18 & S. leptocarpa $1 \mathrm{DC}$. & USDA & Afghanistan & 12 & \multirow{2}{*}{ Sesbania } \\
\hline 19 & S. leptocarpa 2 & USDA & Turkey & 12 & \\
\hline 20 & S. macrantha Phillips. \& Hutch. & ILCA & Tanzania & 12 & Sesbania \\
\hline 21 & S. microphylla Phillips. \& Hutch. & ILCA & Tanzania & 12 & Sesbania \\
\hline 22 & S. pachycarpa 1 DC. & ILCA & Senegal & 14 & \multirow{2}{*}{ Sesbania } \\
\hline 23 & S. pachycarpa 2 & USDA & Kongo & 14 & \\
\hline 24 & S. quadrata Gill. & ILCA & Tanzania & 12 & Sesbania \\
\hline 25 & S. rostrata Bremek. \& Oberm. & ILCA & Tanzania & 12 & Sesbania \\
\hline 26 & S. sericea 1 (Willd.) Link. & ILCA & Tanzania & 12 & \multirow{3}{*}{ Sesbania } \\
\hline 27 & S. sericea 2 & ILCA & Tanzania & 12 & \\
\hline 28 & S. sericea 3 & $\begin{array}{ll}----- \\
--\end{array}$ & Egypt & 12 & \\
\hline 29 & S. sesban 1 (L.) Merr. & USDA & India & 12 & \multirow{5}{*}{ Sesbania } \\
\hline 30 & S. sesban 2 & USDA & Taiwan & 12 & \\
\hline 31 & S. sesban 3 & USDA & Taiwan & 12 & \\
\hline 32 & S. sesban 4 & USDA & Brazil & 12 & \\
\hline 33 & S. sesban 5 & $\begin{array}{ll}----- \\
--\end{array}$ & Egypt & 12 & \\
\hline 34 & S. speciosa 1 & ILCA & Ethiopia & 12 & \multirow{2}{*}{ Daubentonia } \\
\hline 35 & S. speciosa 1 & USDA & Pakistan & 12 & \\
\hline 36 & S. tetraptera Hochst. ex Baker & USDA & Swaziland & 24 & Agati \\
\hline 37 & S. virgata Cav.) Pers. & USDA & Uruguay & 12 & Daubentonia \\
\hline
\end{tabular}


For AFLP finger printing, seeds of all accessions were soaked in tap water for two days and germinated in small pots in the glasshouse at Miami University, Oxford, Ohio, USA. Leaves of actively growing seedlings were harvested on ice, frozen in liquid nitrogen, and stored at $-80^{\circ} \mathrm{C}$ for DNA extraction. For DNA extraction, a modified CTAB method (Saghai-Maroof et $a l .$, 1984) was used. Leaflets were powdered in liquid nitrogen using a mortar and pestle, and homogenized in $0.75 \mathrm{ml}$ hot $4 \times$ CTAB buffer containing $1 \%$ PVP, $1 \%$ Na-bisulphite, and $0.2 \% \quad \beta$-mercaptoethanol. The tubes were incubated for $30 \mathrm{~min}$ in a $60^{\circ} \mathrm{C}$ water bath with occasional gentle mixing. The mixture was emulsified with $0.5 \mathrm{ml}$ of chloroform-isoamyl alcohol (24:1) and centrifuged at 10,000 $\mathrm{g}$ for $5 \mathrm{~min}$ and the aqueous layer was pipetted into a new tube, mixed with $0.5 \mathrm{ml}$ cold isopropanol, kept at $-20^{\circ} \mathrm{C}$ for $30 \mathrm{~min}$, and centrifuged at 12,000 $\mathrm{g}$ for $10 \mathrm{~min}$. The alcohol was discarded and the pellet was washed in $0.75 \mathrm{ml} \mathrm{76 \%} \mathrm{EtOH/0.01} \mathrm{M} \mathrm{NH}_{4} \mathrm{OAC}$ for $5 \mathrm{~min}$ followed by

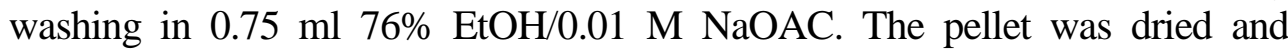
suspended in $0.2 \mathrm{ml}$ TE buffer, and $1 \mu \mathrm{l}$ RNase was added.

AFLP analysis was performed using the ABI PRISM fluorescent dye labeling and detection protocol (Perkin Elmer, USA) based on the method of Vos et al. (1995), with slight modifications. Genomic DNA (500 ng) was double-digested with EcoRI and MseI restriction enzymes and ligated to EcoRI and MseI adapters by incubating in a total volume of $11 \mu \mathrm{l}$ for $4 \mathrm{hrs}$ at $37^{\circ} \mathrm{C}$. The restriction/ligation $(\mathrm{R}+\mathrm{L})$ product was diluted to $200 \mu \mathrm{l}$ and stored at $4^{\circ} \mathrm{C}$ for pre-amplification, or stored at $-20^{\circ} \mathrm{C}$ for later use. Five $\mu 1$ of the $\mathrm{R}+\mathrm{L}$ product were pre-amplified with EcoRI $+\mathrm{A}$ and $M s e \mathrm{I}+\mathrm{C}$ primers in a total volume of $20 \mu \mathrm{l}$ in a thermocycler for 25 cycles at $94^{\circ} \mathrm{C}$ denaturation $(20 \mathrm{sec}), 56^{\circ} \mathrm{C}$ annealing $(30 \mathrm{sec})$, and $72^{\circ} \mathrm{C}$ extension $(2 \mathrm{~min})$, with initial hold at $72^{\circ} \mathrm{C}$ and a final old at $60^{\circ} \mathrm{C}$ for $30 \mathrm{~min}$. The pre-selective amplification product was diluted $15 \mathrm{X}$ in $0.1 \mathrm{TE}$ buffer and stored at $4^{\circ} \mathrm{C}$ for amplification.

Five $\mu 1$ of the above solution were used as a template for selective amplification using three 5'end labeled EcoRI +3 primers (ACA, blue; AAG, green; and ACC, yellow) and three MseI +3 primers (CAC, CTC, and CTT). Amplification was conducted in a total volume of $15 \mu \mathrm{l}$ for 9 cycles at $94^{\circ} \mathrm{C}(2 \mathrm{~min}), 56^{\circ} \mathrm{C}(30 \mathrm{sec})$, and $72^{\circ} \mathrm{C}(2 \mathrm{~min})$, reducing the annealing temperature by one degree per cycle, followed by 21 cycles at $94^{\circ} \mathrm{C}(2 \mathrm{~min}), 56^{\circ} \mathrm{C}(30 \mathrm{sec})$ and $72^{\circ} \mathrm{C}(2 \mathrm{~min})$, and a hold at $60^{\circ} \mathrm{C}$ for 30 min. Two $\mu$ l of this product were mixed with $20 \mu$ l of deionized formamide and $0.5 \mu \mathrm{l}$ of GeneScan 500 ROX internal size standard in a $0.5-\mathrm{ml}$ tube, 
denatured at $95^{\circ} \mathrm{C}$ for $5 \mathrm{~min}$, and analyzed by capillary electrophoresis on an automated Perkin Elmer ABI 310 DNA sequencer with an injection time of $12 \mathrm{sec}$ and a run time of $30 \mathrm{~min}$.

AFLP fragment profiles produced by the nine primer pair combina-tions were printed on photographic paper for manual scoring. The presence (1) or absence (0) of bands from 50 to $350 \mathrm{bp}$ was scored (Fig. 1). Only poly-morphic bands scored in at least two accessions were considered for analysis; uncertain fragments were scored as uncertain (?). Distance trees were constructed using Dice and Jaccard similarity coefficients using UPGMA (Sokal \& Michener, 1958) and Neighbor-joining (Saitou \& Nei, 1987) tree building methods with the software NTSYS-pc 2.1 (Rohlf, 1993).

\section{Results and Discussion}

The nine primer pair combinations for EcoRI and MseI produced considerable variation in the AFLP banding profiles. Over 400 AFLP bands have been scored in the examined 37 accessions of Sesbania. Of these bands, 138 have been found polymorphic and were used for the analyses to construct NJ and UPGMA trees. The AFLP banding profile for the 37 accessions of Sesbania following DNA digestion with EcoRI and MseI, and amplifying the fragments in the presence of the CTC MseI adapter and the AAG EcoRI adapter are illustrated in Fig. 1.

The neighbor joining ( $\mathrm{NJ}$ ) tree based on the analysis of AFLP polymorphism (Fig. 2) clearly distinguished the examined species in two major groups; a small one comprising species in the two subgenera Agati and Daubentonia and a large one that comprises species in subgenus Sesbania (see table 1). The small group is clearly divided into two subgroups at a high level of distance coefficient; one composed of the two accessions of $S$. speciosa and $S$. virgata that belong to subgenus Daubentonia and the other comprised of S. formusa, S. grandiflora and $S$. tetraptera that belong to subgenus Agati. 
$\begin{array}{lllllllllllllllllllllllllllllllllllll}0 & 0 & 0 & 0 & 0 & 0 & 0 & 0 & 0 & 1 & 1 & 1 & 1 & 1 & 1 & 1 & 1 & 1 & 1 & 2 & 2 & 2 & 2 & 2 & 2 & 2 & 2 & 2 & 2 & 3 & 3 & 3 & 3 & 3 & 3 & 3 & 3\end{array}$

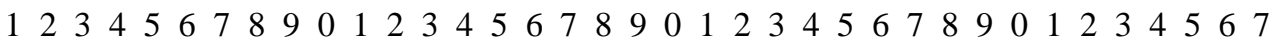

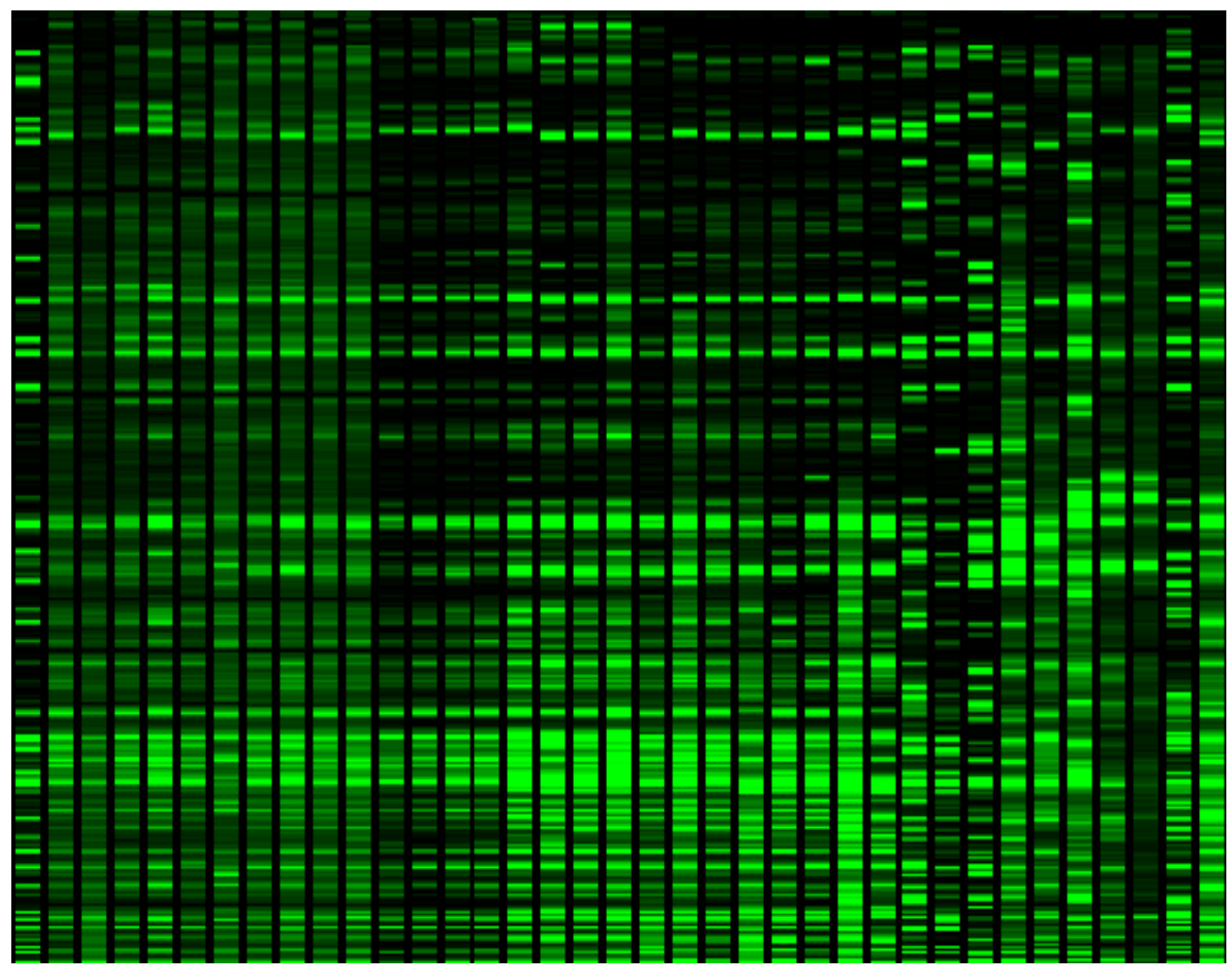

Figure 1. AFLP banding profile for the 37 accessions and species of Sesbania, DNA was digested with EcoRI and MseI, and fragments were amplified using PCR in the presence of the MseI adapter CTC, and the AAG EcoRI adapter. 


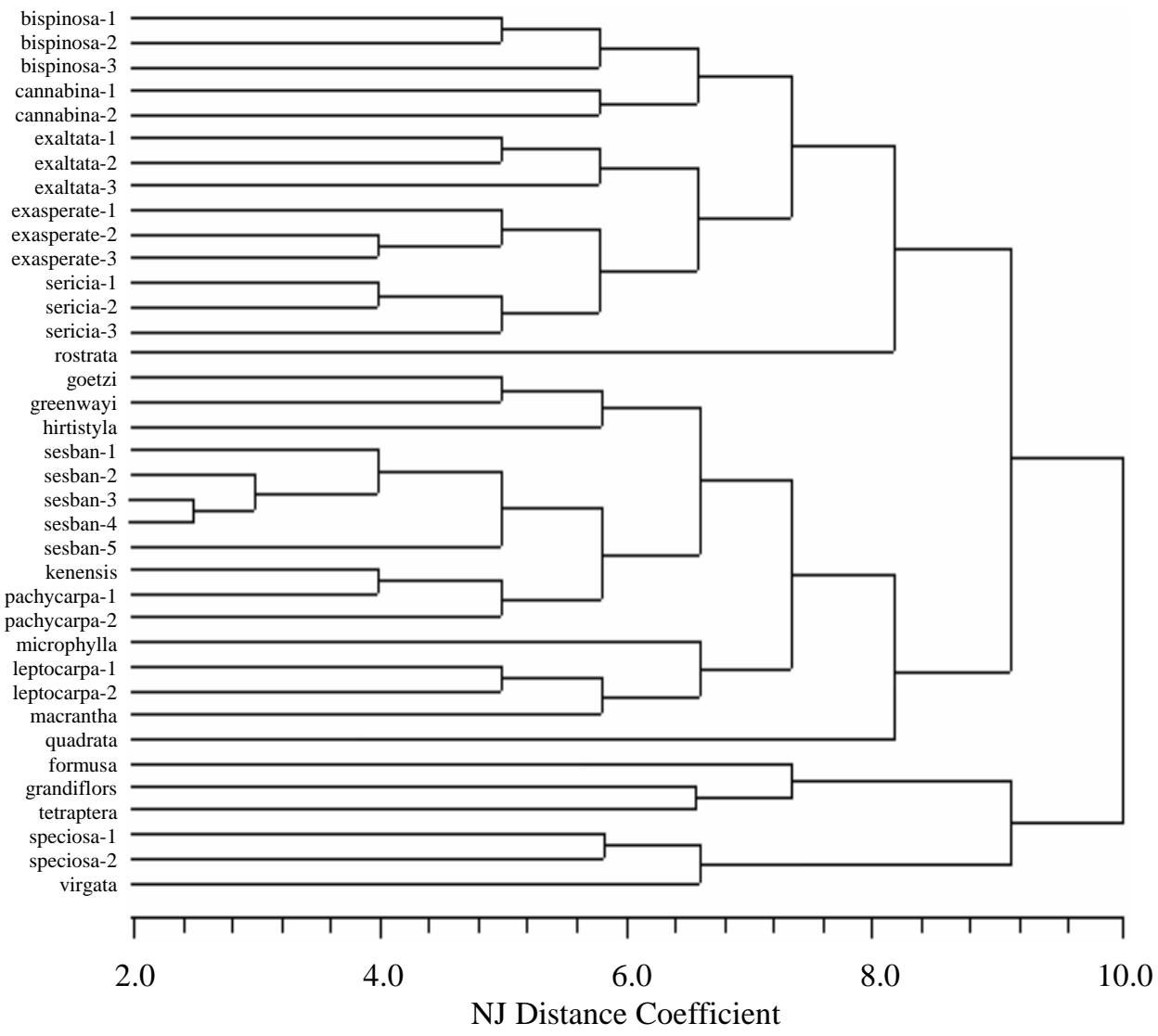

Figure 2. The relationship between accessions and species of Sesbania, based on AFLP data, as demonstrated by the NJ average distance tree. 
The major group in the $\mathrm{NJ}$ tree that comprises species of subgenus Sesbania is divided into two groups. In one of these groups $S$. quadrata is clearly distinguished from a group comprised of 15 other accessions of mostly African species clustered in two subgroups, a small one that includes $S$. macrantha, two accessions of $S$. leptocarpa and $S$. microphylla and a large one that includes two clusters; one comprising the two accessions of $S$. pachycarpa and the five accessions of $S$. sesban and the other $S$. goetzi, $S$. greenwayi and $S$. hirtistyla. In the second group, $S$. rostrata is distinguished from 14 accessions of mostly non African species (Table 1; Fig. 1) that are also delimited in two subgroups; one of nine accessions in two clusters; one comprising $S$. sericia (3 accessions) and $S$. exasperate (3 accessions) and the other the three accessions of $S$. exaltata. The other subgroup is composed of two clusters; one comprising the accessions of $S$. bispinosa and the other accessions of $S$. cannabina.

In the UPGMA tree (Fig. 3) the species in subgenus Daubentonia ( $S$. speciosa and $S$. virgata) are separated together as a small group from a major group that comprises the species in the other two subgenera. However, the species in the two subgenera Agati and Sesbania are divided into two groups. In one of these groups, the species of subgenus Agati ( $S$. formusa, S. grandiflora and S. tetraptera) are delimited together and are clearly separated from another two subgroups comprising 15 accessions of subgenus Sesbania. One of these subgroups includes the two accessions of $S$. leptocarpa (two accessions), $S$. hirtistyla, $S$. greenwayi and $S$. microphylla. The other larger group is comprised of the five accessions of $S$. sesban, and $S$. keninses as well as the two accessions of $S$. pachycarpa, in addition to $S$. goetzi and $S$. macrantha, which are only associated at a high distance coefficient.

The other group is divided into two subgroups; a large one that comprises ten accessions and small one of six accessions. In the large subgroup, the three accessions of $S$. sericia are distinguished from another two clusters; one includes the three accessions of $S$. exasperata and the other $S$. quadrata and the three accessions of $S$. exaltata, in the latter cluster $S$. quadrata is clearly differentiated from the accessions of $S$. exaltata at a high distance coefficient. The other small subgroup is delimited in two clusters; one comprising the three accessions of S. bispinosa and the other includes $S$. rostrata and the two accessions of $S$. cannabina that are clearly distinguished from each other at high distance coefficient. 
The AFLP finger printing of Sesbania species show that accessions of the same species, from different origins, have closer genetic affinity to each other than to accessions of other species. This is reflected in the topology of both the NJ and UPGMA trees. This observation is correlated with intarspecific resemblances in karyotype features (Abou-El-Enain, et al., 1998; El-Shazly \& Abou-El-Enain, 1999) and similarities in storage seed protein electrophoretic profiles (Saraswati et al., 1993; Badr et al., 1998). However, close inspection of AFLP profiles and of the topology of the distance trees shows more genetic diversity between different accessions of the same species that is not manifested in the karyotype features or seed protein electrophoretic profile. Considerable AFLP polymorphism is particularly evident among accessions of $S$. bispinosa, S. cannabina, S. exaltatat, $S$. sesban, and $S$. speciosa in both the NJ tree and UPGMA trees. This polymorphism may be useful markers for selection of desired traits in breeding of selected lines of Sesbania species.

The NJ and UPGMA trees clearly delimited the species in subgenus Daubentonia (S. speciosa and S. virgata) and the species in subgenus Agati (S. formusa $S$. grandiflora and S. tetraptera) as two different groups from other species that have been delimited in subgenus Sesbania. This is in agreement with the current systematic treatment of the genus. Species of subgenus Agati are characterized by large flowers, elliptic standard and reniform oblong seeds (Monteiro, 1994). The delimitation of subgenus Agati is also correlated with the karyotype criteria; species of this subgenus are mostly polyploid with a tetraploid number of $2 n=24$ while those in the other two subgenera are mostly diploid with $2 n=12$ (Abou-El-Enain et al., 1998; El-Shazly \& Abou-Enain, 1999). The separation of subgenus Agati is also supported by evidence of seed protein electrophoretic data (Badr et al., 1998). In line with these evidences the AFLP data, as illustrated in the UPGMA tree reflect the view of Baily (1924) and Maberly (1987) suggesting the treatment of subgenus Agati as a separate genus related to Sesbania. However, the topology of NJ indicate the retention of this subgenus as part of genus Sesbania as suggested by Monteiro (1994) supporting the view of Gillet (1963), Burbidge (1965) and Sachet (1987). 


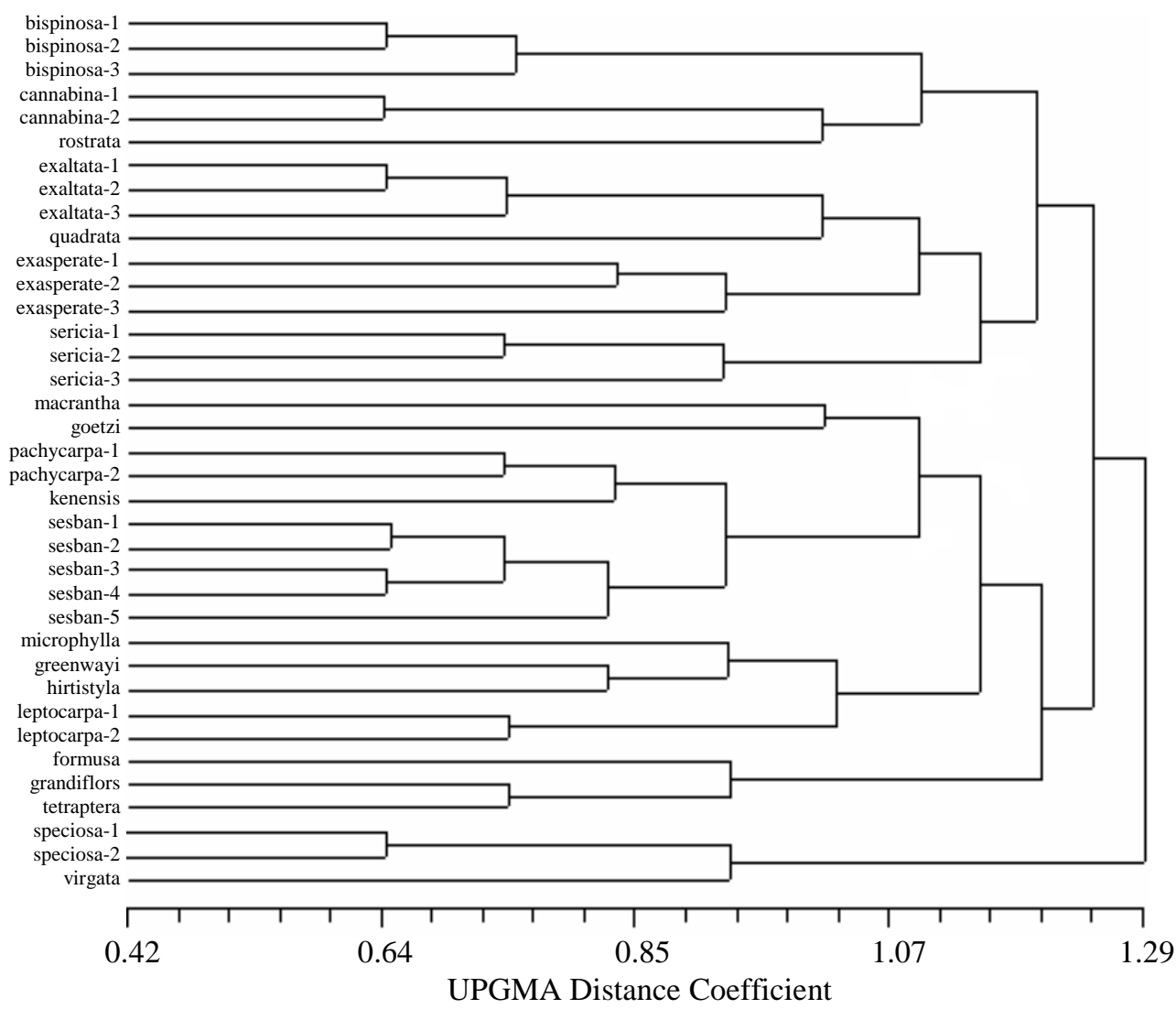

Figure 3. The relationship between accessions and species of Sesbania, based on AFLP data, as demonstrated by the UPGMA tree. 
Compared to subgenus Agati species in the two subgenera, Sesbania and Daubentonia, have smaller flowers, suborbicular standard and cylindrical to oblong seeds (Monteiro, 1994). The species of the two subgenera are mostly diploid with $2 n=12$ but the species in subgenus Daubentonia have shorter chromosomes and more asymmetric karyotypes (Abou-El-Enain et al., 1998; El-Shazly \& Abou-El-Enain, 1999). Species in this subgenus were also recognized as a separate group based on evidence from seed protein electrophoretic data (Badr et al., 1998). The AFLP polymorphism, as illustrated in the NJ and UPGMA trees, may be considered as support for the separation of subgenus Daubentonia in Sesbania and support its delimitation from the other two subgenera as based on similarities in morphological criteria, (Gillet, 1963; Burbidge, 1965; Sachet, 1987).

The AFLP data revealed considerable genetic polymorphism among species in subgenus Sesbania. This is not congruent with the possibility of hybridization between some species in this subgenus (Lewis, 1988; Heering \& Hanson, 1993). The high level of genetic diversity as revealed by AFLP data may be due to the different origins from, which the examined materials were obtained. Heering \& Hanson (1993) noted that crossing, among species, in subgenus Sesbania, may be encouraged by the overlapping distribution of closely related species and is indicative of a close phylogenetic relationship between them (Lewis, 1988). The delimitation of species in the subgenera Agati and Daubentonia from species in subgenus Sesbania, particularly in the NJ tree, support the view of Badr et al. (1998) and El-Shazly \& Abou-El-Enain (1999) that subgenus Sesbania may be the center from which species of the other two subgenera have been derived.

Goldblatt (1981) considered the genus as a monophyletic group in the tribe Robinieae. The monophyly of the genus is supported by the occurrence of seven common bands in the seed protein electrophoretic profile of 15 species (Saraswati et al., 1993) and of eight bands common to 24 species (Badr et al., 1998) of the genus. The results reported by the latter authors supported the view that species in the subgenera Agati and Daubentonia are distinguished as two groups that could have been derived from species in subgenus Sesbania. However, seed protein data did not reveal the level of polymorphism illustrated by the AFLP data. This may be due to the limited possible variation among the types of seed storage proteins that are controlled by few genes compared the AFLP polymorphism that results from nucleotide changes across the whole genome (Vos et al., 1995; Powell et al., 1996). The grouping of species in 
subgenus Sesbania indicate relationships that point out the need for further investigation on the phylogeny and biogeography of the genus.

\section{Acknowledgement}

I'm grateful to Professor Linda Watson, Head of Botany Department of Miami University, Oxford, Ohio, USA for providing facilities to conduct the AFLP finger printing. The assistance of Professor Abdelfattah Badr of Tanta University, Egypt in the publication of this paper is appreciated. I'm also indebted to the Gene Banks that had kindly provided material of the examined accessions and to Ain Shams University and the International Office of Miami University, for financial supprt.

\section{References}

Abou-El-Enain, M.M., El-Shazly, H.H. and El-Kholy, M.A. 1998. Karyological studies in some African species of the genus Sesbania (Fabaceae). Cytologia 63: 1-8.

Al-Nowaihi, A.S., Khalifa, S.F., Badr, A. and Sharawy, S.M. 2002. Species relationships of Astragalus L. in Egypt based on storage seed protein electrophoretic criteria. Proc. $2^{\text {nd }}$ Int. Conf., Biol. Sci., Faculty of Science, Tanta University, April 27-28, vol. 2, pp 174-188.

Bachman, K. 1998. Species as units of diversity: an outdated concept. Theory in Biosci 117: 213-230.

Badr, A. 1995. Electrophoretic studies of seed proteins in relation to the chromosomal criteria and relationships of some samples of Trifolium. Taxon 44: 183-191.

--------, Abou-El-Enain M.M. and El-Shazly H.H. 1998. Variation in seed protein electrophoretic pattern and species relationships in Sesbania (Fabaceae). Proc. th $^{\text {th }}$ Egypt. Bot. Conf., 24-26 Nov. vol. 3, pp. 393-501. , El-Shazly, H.H. and Abou El-Enain, M.M. 2000. Seed protein diversity and its implications on the relationships in the genus Lathyrus L. (Fabaceae). Proc. First Int. Conf. Biol. Sci., Faculty of Science, Tanta University, May 14-15, pp 493-501. -, Müller K., Schäfer-Pregl R., El-Rabey H., Effgen S., Ibrahim H.H., Pozzi C., Rohde W. and Salamini F. 2000. On the origin and domestication history of barley (Hordeum vulgare). Mol. Biol. Evol. 17: 499-510.

, El-Shazly H.H., El-Rabey, H. and Watson, L.E. 2002. Systematic relationships in Lathyrus section Lathyrus (Fabaceae) based on amplified fragment length polymorphism (AFLP) data. Can. J. Bot. 80: $962-969$. 
Baily, L.H. 1924. Manual of cultivated plants. Macmillan, New York.

Bentham, G. 1859. Papilionaceae. In Martius, C.F.P. (ed.), Flora Brasiliensis .vol. 15, Part 1, Munich, Germany.

Burbidge, N.T. 1965. The Australian species of Sesbania Scopali (Leguminosae). Aust. J. Bot. 13: 103-141.

Evans, D.O. 1990. What is Sesbania? Botany, taxonomy, plant geography, and natural history of the perennial members of the genus. In: Macklin, O. and Evans, D.O. (eds.) Perennial Sesbania Species in Agroforestry Systems. Waimanalo: Nitrogen Fixing Tree Association, 1990. pp. 5-16.

-- and Rotor, P.P. 1987. Sesbania in Agriculture. Boulder Co., Westview Press, USA.

El-Rabey, H., Badr, A., Schäfer-Pregl, R., Martin W. and Salamini, F. 2002. Speciation and species separation in Hordeum L. (Poaceae) resolved by discontinuous molecular markers. Plant Boil. 4: 567-575

El-Shazly, H.H. and Abou-El-Enain M.M. 1999. Chromosomal criteria of some Sesbania species and their taxonomic inferences. Bull. Fac. Sci. Assiut Univ. 28:123-132.

, Badr, S.F. and Badr, A. 2006. Relationships of Lupinus species based on variation in seed protein electrophoretic profile. Taeckholmia 26:1-15

Fedorov, A. 1974. Chromosome numbers of flowering plants. Koeltz Science Publishers, Königstein/West-Germany.

Forni-Martins, E.R., Franchi-Tanibata, M. and Cardelli-de-Laucena, M. 1994. Karyotypes of seven species of Sesbania Scop. (Fabaceae). Cytologia 59: 479-482.

Gillet, J.B. 1963. Sesbania in Africa (excluding Madagascar) and Southern Arabia. Kew Bull. 17: 19-159.

Goldblatt, P. 1981. Cytology and phylogeny of Leguminosae. In Polhill, RM and Raven, PH (eds.) Advances in Legume Systematics, part 2, Royal Botanic Gardens, Kew, pp 427-463.

1985. Index to plant chromosome numbers 1982-1983. Monographs in Systematic Botany vol. 13, Missouri Botanical Garden, Saint Louis.

1988. Index to plant chromosome numbers 1984-1985. Monographs in Systematic Botany vol. 23, Missouri Botanical Garden, Saint Louis. 

- and Johnson, D.E. 1991. Index to plant chromosome numbers 1988-1989. Monographs in Systematic Botany vol. 40, Missouri Botanical Garden, Saint Louis.

Heering, J.H. and Hanson, J. 1993. Karyotype analysis and inter-specific hybridization in three perennial Sesbania species (Leguminosae). Euphytica 71: 21-28.

Heun, M, Schäfer-Pregl R., Klawan, D., Castagna, R., Accerbi, M., Borghi, B. and Salamini F. 1997. Site of einkorn wheat domestication identified by DNA fingerprinting. Science 278:1312-1314

Hill, M., Witsenboer, H., Zabeau, M., Vos, P., Kesseli, R. and Michelmore, R. 1996. PCR-based fingerprinting using AFLPs as a tool for studying genetic relationship in Lactuca species. Theor. Appl. Genet. 93: 1202-1210

Joshua, D.C. and Bhatia, C.R. 1989. Karyotype analysis in Sesbania species. Nucleus-Calcutta 32: 161-163.

Kardolus, J.P., van Eck H.J., and van den Berg, R.G. 1998. The potential of AFLPs in biosystematics: a first application in Solanum taxonomy (Solanaceae). Pl. Syst. Evol.10: 87-103

Lewis, G.P. 1988. Sesbania Scop. In the Flora Zambesiaca region. Kirika 13: 11-51.

Lubis, S.H., Okada, H. and Sastrapraja, S. 1981. On the cytology of four species of Sesbania. Ann. Bogor. 7: 115-127.

Maberly, D.J. 1987. The Plant book; A portable dictionary of the higher plants. Cambridge University press, New York.

Martin, W. and Salamini, F. 2000. A meeting at the gene biodiversity and natural history. EMBO Reports 1: 208-210.

Massa, A.N., Larsen, S.R., Jensen, K.B., and Hole, D.J. 2001. AFLP variation in Bromus section Ceratochloa germ plasm of Patagonia. Crop Sci 41: 1609-1616

Monteiro, R. 1994. The species of Sesbania Scop. (Leguminosae) in Brazil. Arq. Biol. Tecnol. 37: 309-331.

Parihar, R.S. and Zadoo, S.N. 1987. Cytological studies of the genus Sesbania Scop. I- Karyotype. Cytologia 52: 507-512.

Powell W., Morgante, M., Andre, C., Hanafey, M., Vogel, J., Tingey, S.and Rafalaski, A. 1996. The comparison of RFLP, RAPD, AFLP and SSR (microsatellite) markers for germ plasm analysis. Mol. Breed. 3:225238

Rohlf, F.J. 1993. NTSYS-pc, Numerical Taxonomy and Multivariate Analysis System. Applied Biostatistics Inc, New York. 
Saghai-Maroof, M.A.; Soliman, K.M.; Jorgensen, R.A.; and Allard, R.W. 1984. Ribosomal DNA spacer-length polymorphism in barley. Mendelian inheritance, chromosomal location, and population dynamics. Proc. Natl. Acad. Sci. USA 81: 8014-8018.

Saitou, N. and Nei, M. 1987. The neighbor-joining method: a new method for reconstruction phylogenetic trees. Mol. Biol. Evol. 4: 406 - 425.

Sachet, M.H. 1987. The littorial species of Sesbania (Leguminosae) and its relatives in the South Pacific islands. Adansonia 9: 3-28.

Salimuddin, R.B. 1993. Karyological studies in the genus Sesbania. Cytologia 58: 241-126.

Saraswati, R., Matoh, T., Sasai, T., Phupaibul, P., Lumpkin, T., Kobayashi, M. and Sekiya, J. 1993. Identification of Sesbania species from electrophoretic patterns of seed proteins. Trop. Agric. 70: 282-285.

Sokal, R.R. and Michener, C.D. 1958. A statistical method for evaluating systematic relationships. Univ. Kansas Sci. Bull. 28: 1409-1438.

Vos, P., Hogers, R., Bleckers, M., Beijans, M., van de Lee, T., Hornes, M., Frijiters, A., Pot, J., Oeleman, J. and Zabeau, M. 1995. AFLP: New technique for DNA fingerprinting. Nucleic Acids Res. 23: 4407-4414. 